\title{
Whey Fermentation for Protease Production Using Bacillus thuringiensis Isolated from Mangrove Rhizosphere Soil in Jazan, Saudi Arabia
}

\author{
Khaled E. El-Gayar ${ }^{1,2 *}$, Ashraf M. Essa ${ }^{1,3}$, Emad A. Abada ${ }^{1,4}$ \\ ${ }^{1}$ Biology Department, Faculty of Science, Jazan University, Jazan, Kingdom of Saudi Arabia \\ ${ }^{2}$ The Holding Company for Biological Products and Vaccines, Vacsera, Cairo, Egypt \\ ${ }^{3}$ Botany Department, Faculty of Science, Fayoum University, Fayoum, Egypt \\ ${ }^{4}$ Botany and Microbiology Department, Faculty of Science, Helwan University, Cairo, Egypt
}

Received: 12 May 2019

Accepted: 9 July 2019

\begin{abstract}
Utilization of whey as a fermentation substrate offers an opportunity to produce valuable products. The current work was carried out in order to evaluate the capability of bacteria isolated from mangrove rhizosphere soil in Jazan (Kingdom of Saudi Arabia) for the production of extracellular protease using fresh whey as a substrate. The bacterial isolate with the maximum proteolytic activity was identified by biochemical and 16S rDNA techniques as Bacillus thuringiensis. The factors affecting bacterial growth and protease production were investigated. The maximum protease production was achieved with minimal medium supplemented with $50 \%$ whey, $1 \%$ skim milk, $10 \% \mathrm{NaCl}$, and $1 \% \mathrm{CaCl}_{2}$ at $\mathrm{pH}$ 7.0 and temperature $37^{\circ} \mathrm{C}$. In a fermentation experiment, B. thuringiensis utilized whey as a substrate for the production of extracellular protease with a high specific activity. The protease was precipitated using ammonium sulfate, followed by dialysis to yield 9.7-fold purification with 70.8\% recovery. After fermentation, there was a remarkable reduction of BOD, COD, and COD/BOD ratio. A high yield of biomass with a promising protein level was obtained. In conclusion, B. thuringiensis demonstrated a high capability for extracellular protease and single cell protein production using whey as a costeffective medium that could minimize environmental pollution.
\end{abstract}

Keywords: Bacillus thuringiensis, whey fermentation; protease production, single-cell protein

\section{Introduction}

Industrial wastes are considered a real source of environmental pollution and health hazards since various types of microorganisms, including pathogens,

*e-mail: k_elgayar@yahoo.com have the ability to grow on them [1]. Food industries are characterized by high water consumption and production of huge amounts of effluents and sludge per unit of production [2]. Milk contains nutritive compounds and biologically active ones such as caseins and whey proteins. Caseins constitute $80 \%$ of the total protein present in milk. Meanwhile, the remaining 20\% is comprised of $\alpha$-lactalbumin, $\beta$-lactoglobulin, and immunoglobulins $[1,3]$. The annual production of whey 
is more than 160 million tons yearly worldwide. The main ingredients of whey are water, lactose, lactic acid, proteins, lipids, vitamins and mineral salts, which give a high biochemical oxygen demand and chemical oxygen demand [4]. Consequently, the high load of pollutants in the partially treated or untreated dairy wastewater could cause serious environmental and public health problems [3, 5].

Various physicochemical techniques have been applied for wastewater treatment. These methods include sedimentation, flotation, filtration, coagulation, ion exchange, and neutralization. However, these methods have many limitations, such as the use of chemical agents, high cost, and the production of secondary pollutants. Due to these limitations, the application of biological methods for the treatment of wastewater could be a promising alternative approach [6]. Microorganisms are considered potentially to be the most suitable sources of protease for industrial application.

Proteases are a mixture of peptidases and proteinases that catalyze the hydrolysis of protein into amino acids or smaller peptide fractions. Based on the site of action of the enzyme on protein substrates, proteases are classified as endo or exoenzymes. Bacillus species are specific producers of extracellular enzymes. Several proteases have been purified and characterized from many Bacillus strains [3]. Proteases are one of the most important industrial enzymes. Proteases are involved in a wide variety of applications, including bioremediation, detergents, the food industry, the leather industry, pharmaceuticals, the textile industry and waste treatment [7].

The use of dairy wastewater for the production of protease is the eco-friendly and economical approach for bioconversion of these wastes into value-added products, in addition to the reduction of environmental pollution. The present study aims to isolate potent protease-producing bacteria and apply them for the production of extracellular protease and some essential products using fresh whey as a cost-effective medium.

\section{Experimental Procedures}

\section{Isolation and Screening of Proteolytic Bacteria}

Samples were collected from a mangrove rhizosphere along the Red Sea coast in Jazan, KSA. Samples were collected in $1 \mathrm{~L}$ sterilized plastic bottles. Serial dilution was carried out and $50 \mu \mathrm{L}$ of each dilution was inoculated into nutrient agar plates supplemented with $5 \%$ skim milk. After incubation at $37^{\circ} \mathrm{C}$ for $24 \mathrm{hrs}$, colonies forming clear zones, because of hydrolysis of casein, were selected. The selected isolates were purified by the streaking method. The purified isolates were subjected to gelatin hydrolysis test. The procedure was carried out by the inoculation of isolates by stabbing on tube containing nutrient gelatin medium and incubated at $37^{\circ} \mathrm{C}$ for 14 days. The tubes were removed daily and kept at $4^{\circ} \mathrm{C}$ for $15-30$ minutes to check the liquefaction of gelatin [8]. Furthermore, a preliminary assay of protease activity of the selected isolates was carried out according to Zaghloul et al. [9]. A minimal medium $\left(\mathrm{NH}_{4} \mathrm{Cl}, 0.5 \mathrm{~g} ; \mathrm{K}_{2} \mathrm{HPO}_{4}, 0.3 \mathrm{~g} ; \mathrm{KH}_{2} \mathrm{PO}_{4}\right.$, $0.4 \mathrm{~g} ; \mathrm{NaCl}, 0.5 \mathrm{~g} ; \mathrm{MgCl}_{2} 6 \mathrm{H}_{2} \mathrm{O}, 0.1 \mathrm{~g}$; and yeast extract $0.1 \mathrm{~g} / \mathrm{L}$ ) supplemented with $5 \%$ whey was inoculated with bacterial isolates and incubated at $37^{\circ} \mathrm{C}$ with shaking $(150 \mathrm{rpm})$ for $72 \mathrm{hrs}$. After centrifugation at $12000 \mathrm{rpm}$ for $20 \mathrm{~min}$, the supernatant containing protease was collected. Skim milk (1\%) was dissolved in $20 \mathrm{mM}$ Tris- $\mathrm{HCl}$ buffer $(\mathrm{pH} 7.5)$ and $1.5 \%$ agar was added. Holes were pinched to adequate $25 \mu \mathrm{l}$ of the crude enzyme. Plates were incubated overnight at $37^{\circ} \mathrm{C}$ and the clear zones were measured in $\mathrm{mm}$.

\section{Identification of Bacteria}

After Gram staining, the bacterial isolate with maximum proteolytic activity was observed using the light microscope. The phenotypic fingerprint of the isolate was assayed using new Gen III Micro Plate test panel of identification in the Biolog System [10]. After 20 hrs, microplates were read in the Micro Station semi-automated reader and the identification systems software (GEN III database) interpreted the results. To confirm the biochemical identification, the 16S rDNA gene sequencing technique was applied. The genomic DNA was extracted according to Essa [11]. The primers used in the amplification of the 16S rDNA gene were forward primer (F; AGA GTT TGA TCC TGG CTC AG) and reverse primer (R; GGT TAC CTT GTT ACG ACT T). PCR was performed according to Essa et al. [12]. Sequence analysis was performed using the sequence alignment software BLASTn with the National Center for Biotechnology Information (NCBI database; http://www.ncbi.nlm.nih.gov/).

\section{Optimization of Bacterial Growth and Protease Production}

Different parameters such as $\mathrm{pH}$ value (4, 7 and 10), temperature $\left(30,37,45\right.$ and $\left.50^{\circ} \mathrm{C}\right)$, salinity $(1,5$ and $10 \% \mathrm{w} / \mathrm{v}$ of $\mathrm{NaCl})$, whey concentration $(10,20,50$, and $100 \% \mathrm{w} / \mathrm{v})$, skim milk concentration $(0.1,0.5$ and $1 \%$ $\mathrm{w} / \mathrm{v})$, and calcium concentration $(0.1,0.5$ and $1 \% \mathrm{w} / \mathrm{v}$ of $\mathrm{CaCl}_{2}$ ) were optimized to enhance bacterial growth and protease production using whey as a fermentation medium. During the fermentation experiment, the bacterial growth was monitored on NA plates as $\mathrm{CFU} / \mathrm{ml}$ for 4 days. At the same time, the bacterial cultures were centrifuged at $12000 \mathrm{rpm}$ for $20 \mathrm{~min}$ at $4^{\circ} \mathrm{C}$. The supernatants were used for enzyme assay. The protease activity was assayed according to Lin et al. using casein as a substrate and trichloroacetic acid (TCA) as a stop solution. One unit of enzyme is the amount of enzyme that liberates one micromole of tyrosine from casein per $30 \mathrm{~min}$ at $37^{\circ} \mathrm{C}$ [13]. 


\section{Partial Purification of Extracellular Protease Enzyme}

B. thuringiensis cells were grown on $50 \%$ whey supplemented with $1 \%$ skim milk in minimal medium for $72 \mathrm{hrs}$ at $37^{\circ} \mathrm{C}$ with agitation $(150 \mathrm{rpm})$ [14]. Precipitating cells at $12000 \mathrm{rpm}$ was carried out to obtain cell-free supernatant. Ammonium sulfate was added to the cell-free supernatant reaching $65 \%$ saturation. The precipitate was separated by centrifugation at $12000 \mathrm{rpm}$ for 30 minutes at $4^{\circ} \mathrm{C}$. Pellets were resuspended in $0.1 \mathrm{M}$ Tris- $\mathrm{HCl}$ buffer, $\mathrm{pH} 7.5$ containing $10 \mathrm{mM} \mathrm{CaCl}_{2}$, and dialyzed overnight against the same buffer. After that, the sterility test was carried out by streaking the enzyme on trypticase soy agar plates.

\section{Analysis of Whey}

The whey before and after the fermentation process was subjected for various analysis. The fermentation process for $50 \%$ whey in minimal medium inoculated with $1 \%$ B. thuringiensis for $72 \mathrm{hrs}$ at $37^{\circ} \mathrm{C}$ with shaking at $150 \mathrm{rpm}$ was done. The electrical conductivity (EC) and $\mathrm{pH}$ value of fermentation media were measured using a standard $\mathrm{pH}$ meter (Jenway, model 3510, UK). Biological oxygen demand (BOD) and chemical oxygen demand (COD) were estimated according to APHA [15]. Carbohydrate content was calculated according to Abd El-Aziz et al. [16]. Concentrations of glucose in the fermentation medium were determined using kits supplied by Spectrum Diagnostics (Egyptian Co. for Biotechnology, Cairo, Egypt). Total lipids were assayed according to Zollner and Kirsch [17], lipids reacted with sulfuric, phosphoric acids and vanillin to form a pink colored complex, and absorbance was measured at $545 \mathrm{~nm}$. The content of soluble proteins was estimated using the bicinchoninic acid (BCA) assay kit (Sigma-Aldrich BCA-1, B9643), with bovine serum albumin as a standard. The developed purple color was measured spectrophotometrically at $562 \mathrm{~nm}$ [18].

\section{Antimicrobial Susceptibility Test}

Antibiotic susceptibility test was performed to detect possible drug resistance and to assure susceptibility to drugs of choice for particular contamination [19]. The test was carried out using the disc diffusion method. A single bacterial colony was picked using a sterile loop and streaked on the NA plates. A filter paper disk saturated with the following antibiotics - Mast Diagnostics, Bootle, UK; Cefuroxime $30 \mu \mathrm{g}$ $(C X M)$, Erythromycin $15 \mu \mathrm{g}(\mathrm{E})$, Cefoxitin $30 \mu \mathrm{g}$ $(F O X)$, Streptomycin $10 \mu \mathrm{g}(S)$ Pencilin 10 units $\mu \mathrm{g}$ $(P)$, Rifampicin $5 \mu \mathrm{g}$ (RIF), Levofloxacin $5 \mu \mathrm{g}(L E V)$, Sulfamethoxazole-trimethoprim 25-70 $\mu \mathrm{g} \quad(S X T)$, Ampicillin-sulbactam $10 \mu \mathrm{g}(S A M)$, and Azithromycin $15 \mu \mathrm{g}(A Z M)$ - were dispensed onto the plates. Nutrient agar plates containing antibiotic discs were incubated overnight at $35^{\circ} \mathrm{C}[20]$.

\section{Preliminary Experiment of Single-Cell Protein Production}

One liter of minimal medium supplemented with $50 \%$ whey and $1 \%$ skim milk was inoculated with $2 \%$ B. thuringiensis under sterile conditions. Fermentation was carried out at $37^{\circ} \mathrm{C}$ with shaking at $150 \mathrm{rpm}$ for 4 days [21]. Cell growth was measured by determining optical density at $600 \mathrm{~nm}$. Dry cell weight was determined after centrifugation at $12000 \mathrm{rpm}$ for 20 minutes and the pellet was dried at $105^{\circ} \mathrm{C}$ to a constant weight.

\section{Results and Discussion}

\section{Bacterial Isolation and Identification}

The dairy industry comprises the processing of raw milk into various products such as consumer milk, cheese, yogurt, butter, condensed milk, and dried milk. In the dairy industries, large quantities of whey as a byproduct are produced, representing $85-95 \%$ of milk volume and retaining $55 \%$ of milk nutrients [22]. The worldwide production of whey was estimated at $190 \times 10^{6}$ ton/year [23]. Many researchers proposed various biotechnological methods for the treatment of dairy wastes using different microorganisms [1, 2]. In the current study, bacteria with high proteolytic activity were isolated from halophilic habitat (mangrove rhizosphere soil, Jazan, KSA). Skim milk was used during the present investigation because whole milk contains fats that inhibit the growth of proteolytic

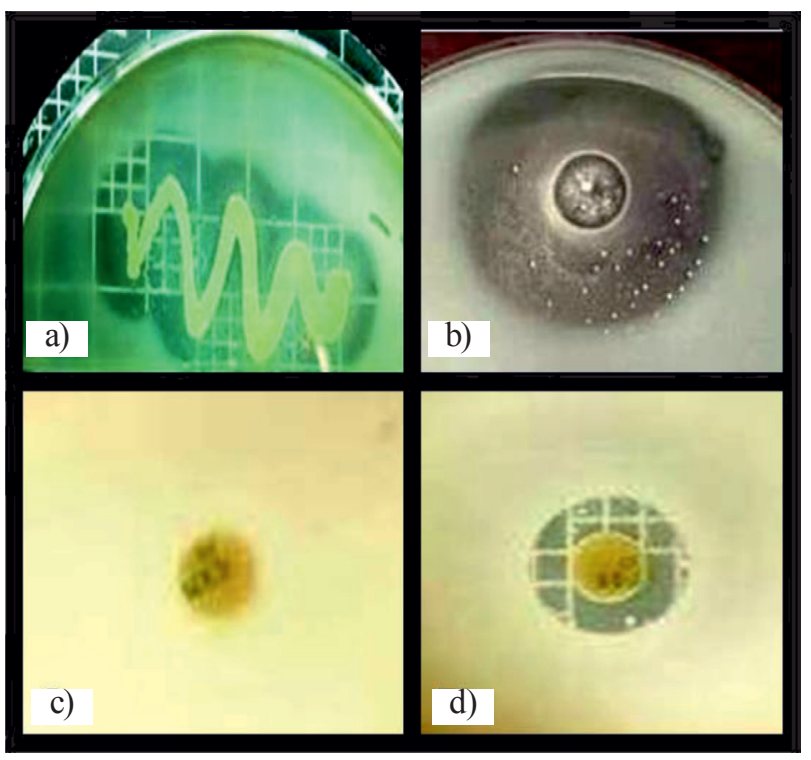

Fig. 1. a) Protease qualitative determination of the bacterial isolate on skim milk nutrient agar, b) Activity of the bacterial extracellular protease on skim agar nutrient is not found, c) and d) Effect of cefuroxime (CXM) and cefoxitin (FOX) on Bacillus thuringiensis, respectively. 
bacteria. Among the different isolates, the one with a maximum zone of clearance on skim milk agar (Fig. 1a) and high capacity for the liquefaction of gelatin was chosen. At the same time, the crude protease of this isolate demonstrated a remarkable activity with casein method (Fig. 1b). Comparable reports about the isolation of protease producing bacteria utilizing nutrient with skim milk medium and/or minimum medium supplemented with skim milk have been documented $[24,25]$. Based on the morphological characteristics and Gram stain, the bacterial isolate was classified as Gram-positive rod-shaped cells. According to the metabolic fingerprints (Table 1), the isolate was identified as Bacillus thuringiensis. The molecular identification of the bacterial isolates was performed using 16S rDNA gene sequencing. The obtained DNA sequences $(500 \mathrm{bp})$ were aligned at the NCBI database.
The isolate was identified as Bacillus thuringiensis with 98\% identity to Bacillus thuringiensis strain (accession number NR114581.1). Various bacteria with high hydrolytic activities belonging to the genus Bacillus have been isolated from a wide range of extreme environments. Wie et al. [26] isolated moderately halophilic bacteria from marine sediment environments. Most of them were able to produce at least one of the hydrolytic activities of protease, amylase, lipase, pectinase and pulluanase, xylanase, and cellulose. Similarly, Nawab et al. [27] isolated a halotolerant protease-producing Bacillus subtilis from salt mines of Karak, Pakistan. In addition, a thermophilic Bacillus subtilis with high amylolytic and proteolytic activities were isolated from hot springs in Jazan, Saudi Arabia [28].

Table 1. Biochemical profile of the bacteria isolated from mangrove rhizosphere soil in Jazan (KSA) using the Biolog System.

\begin{tabular}{|c|c|c|c|c|c|c|c|}
\hline Test & Result & Test & Result & Test & Result & Test & Result \\
\hline D-Raffinose & -ve & $\alpha$-D-Glucose & $+/-$ & D-Sorbitol & -ve & Gelatin & $+\mathrm{ve}$ \\
\hline Pectin & -ve & $\begin{array}{c}\text { Hydroxy- phenylace- } \\
\text { tic acid }\end{array}$ & -ve & Tween 40 & -ve & Dextrin & $+\mathrm{ve}$ \\
\hline$\alpha$-D-Lactose & -ve & D-Mannose & -ve & D-Mannitol & $+/-$ & Glycyl-L-proline & -ve \\
\hline D-Galacturonic acid & $+\mathrm{ve}$ & Methyl pyruvate & $+/-$ & $\gamma$-Amino-butryric acid & -ve & D-Maltose & $+\mathrm{ve}$ \\
\hline D-Melibiose & -ve & D-Fructose & $+\mathrm{ve}$ & D-Arabitol & $+/-$ & L-Alanine & $+/-$ \\
\hline L-Galactonic acid lactone & $+/-$ & \begin{tabular}{|c|} 
D-Lactic acid methyl \\
ester
\end{tabular} & -ve & $\alpha$-Hydroxy-butyric acid & -ve & D-Trehalose & $+/-$ \\
\hline$\beta$-Methyl-D-glucoside & $+/-$ & D-Galactose & $+/-$ & Myo-Inositol & $+/-$ & L-Arginine & $+/-$ \\
\hline D-Gluconic acid & $+\mathrm{ve}$ & L-Lactic acid & $+\mathrm{ve}$ & $\begin{array}{c}\beta \text {-Hydroxy-D, L-butyric } \\
\text { acid }\end{array}$ & -ve & D-Cellobiose & -ve \\
\hline D-Salicin & -ve & 3-Methyl glucose & $+/-$ & Glycerol & -ve & L-Aspartic acid & $+/-$ \\
\hline D-Glucuronic acid & $+/-$ & Citric acid & -ve & $\alpha$-Keto-Butyric acid & -ve & Gentiobiose & -ve \\
\hline N-Acetyl-D-glucosamine & $+/-$ & D-Fucose & -ve & D-Glucose- 6- $\mathrm{PO}_{4}$ & $+\mathrm{ve}$ & L-Glutamic acid & $+/-$ \\
\hline Glucuronamide & $+/-$ & $\alpha$-Keto-Glutaric acid & -ve & Acetoacetic acid & $+\mathrm{ve}$ & Sucrose & -ve \\
\hline $\begin{array}{l}\text { N-Acetyl- } \beta \text {-D- } \\
\text { mannosamine }\end{array}$ & $+/-$ & L-Fucose & -ve & D-Fructose- 6- $\mathrm{PO}_{4}$ & $+\mathrm{ve}$ & L-Histidine & $+/-$ \\
\hline Mucic acid & $+/-$ & D-Malic acid & -ve & Propionic acid & $+/-$ & D-Turanose & $+/-$ \\
\hline $\begin{array}{l}\text { N-Acetyl-D-galactos- } \\
\text { amine }\end{array}$ & $+/-$ & L-Rhamnose & $+/-$ & D-Aspartic acid & -ve & L-Pyroglutamic acid & $+/-$ \\
\hline Quinic acid & -ve & L-Malic acid & $+/-$ & Acetic acid & $+\mathrm{ve}$ & Stachyose & $+/-$ \\
\hline N-Acetyl neuraminic acid & -ve & Inosine & $+/-$ & D-Serine & $+/-$ & L-Serine & $+/-$ \\
\hline D-Saccharic acid & -ve & Bromo-succinic acid & -ve & Formic acid & $+\mathrm{ve}$ & $1 \% \mathrm{NaCl}$ & $+\mathrm{ve}$ \\
\hline $1 \%$ Sodium lactate & $+\mathrm{ve}$ & Troleandomycine & -ve & Lincomycin & $+/-$ & $4 \% \mathrm{NaCl}$ & $+/-$ \\
\hline Nalidixic acid & -ve & Aztreonam & $+\mathrm{ve}$ & Vancomycine & -ve & $8 \% \mathrm{NaCl}$ & $+/-$ \\
\hline $\mathrm{pH} 6$ & $+\mathrm{ve}$ & $\mathrm{pH} 5$ & -ve & Fusidic acid & -ve & Rifamycine SV & -ve \\
\hline Guanidine $\mathrm{HCl}$ & $+\mathrm{ve}$ & Tetrazolium violet & -ve & Lithium chloride & $+\mathrm{ve}$ & Sodium butyrate & $+\mathrm{ve}$ \\
\hline Minocycline & -ve & Niaproof4 & -ve & Tetrazolium blue & -ve & Potassium tellurite & $+\mathrm{ve}$ \\
\hline Sodium bromated & $+/-$ & & & & & & \\
\hline
\end{tabular}




\section{Antimicrobial Susceptibility Test}

The antibiotic susceptibility test was carried out for the bacterial strain $B$. thuringiensis in order to detect its possible drug resistance that could help for the inhibition of microbial contamination during protease production $[19,20]$. The obtained results (Fig. 1c \& d) showed that $B$. thuringiensis was resistant against penicillin, ampicillin-sulbactam, azithromycin, and cefuroxime.

\section{Optimizing of the Bacterial Growth and Protease Production}

Proteases are among the most important class of industrial enzymes, which constitute more than $65 \%$ of the total industrial applications [8, 29]. Industrial production of proteases by microbial fermentation is focused on new methods for cheap production eventually to decrease the production cost [30]. The production cost of industrial enzymes can be minimized using byproducts or wastes generated during the processing of industrial, agricultural and food wastes as substrates. Wastes of dairy industries represent environmental pollution problems that need improved waste management strategies. The use of these wastes as carbon and nitrogen sources could result in a decrease in protease production cost and reduction of environmental pollution. Various factors are known to influence the microbial growth and production of hydrolytic enzymes. These include carbon and energy source requirements, temperature, $\mathrm{pH}$, salinity, nitrogen, phosphorus, and potassium requirement. In the current study, the utilization of whey as a substrate for the growth of B. thuringiensis cells and production of protease was

a)

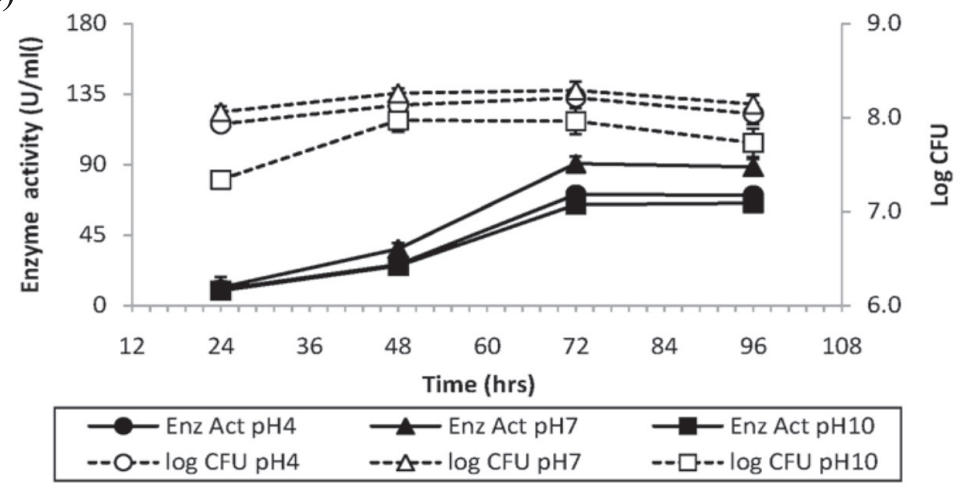

b)

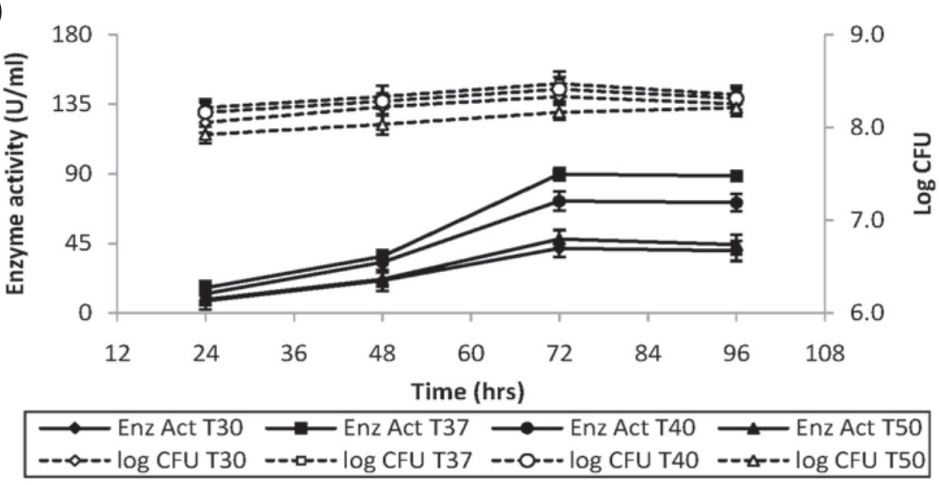

c)

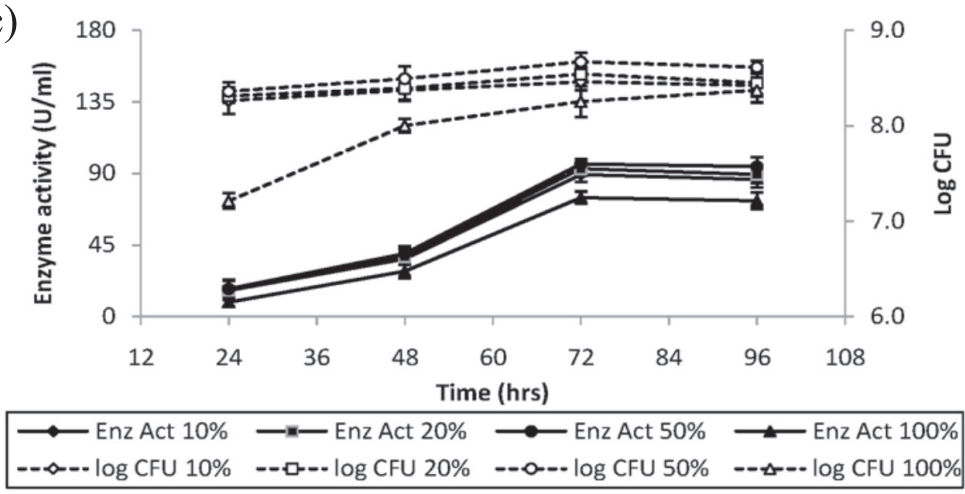

Fig. 2. Optimization of bacterial growth and protease production where a) represents the effect of $\mathrm{pH}, \mathrm{b}$ ) represents the effect of temperature, and c) represents the effect of whey concentration; data are the means of three replications \pm standard errors. 
evaluated under different conditions. B. thuringiensis was inoculated into minimal medium supplemented with $10 \%$ whey and $\mathrm{pH}$ was adjusted at 4,7 and 10 and incubated at $37^{\circ} \mathrm{C}$ for 4 days. The maximum level of protease production $(90.65 \mathrm{U} / \mathrm{ml})$ and bacterial growth (8.38 $\log \mathrm{CFU} / \mathrm{ml}$ ) was recorded at $\mathrm{pH} 7$ during the third day (Fig. 2a). Sharmin et al. [31] and Abusham et al. [32] recorded comparable results where the optimum growth of Bacillus amovivorus and Bacillus subtilis was recorded at neutral $\mathrm{pH}$ value. It was reported that the $\mathrm{pH}$ of culture has been shown to strongly affect many enzymatic processes, and the transportation of various components across the cell membrane [33]. Regarding the effect of temperature on the fermentation process, the bacterial cells were inoculated into minimal medium supplemented with $10 \%$ whey and incubated at different temperatures. The highest bacterial growth (8.47 log
$\mathrm{CFU} / \mathrm{ml}$ ) was recorded at $37^{\circ} \mathrm{C}$ after 3 days, while the level of proteolytic activity was higher at $37^{\circ} \mathrm{C}$ (89.71 U/ml) followed by $45^{\circ} \mathrm{C}, 30^{\circ} \mathrm{C}$, and $50^{\circ} \mathrm{C}$ (Fig. $2 \mathrm{~b}$ ). At the same time, the remarkable stability of protease activity was observed under high temperature. These results are in agreement with those obtained by Abusham et al. [32], where the maximum growth and production of protease by Bacillus subtilis was recorded at $37^{\circ} \mathrm{C}$. In general, the temperature was found to influence the secretion of the extracellular enzymes through changing the physical properties of the cell membrane [34].

The concentration of whey as a substrate in the bacterial fermentation process is very important because it acts as a carbon and nitrogen source. The minimum medium was supplemented with different whey concentrations and incubated at $37^{\circ} \mathrm{C}$. The obtained data (Fig. 2c) demonstrated an increase of bacterial

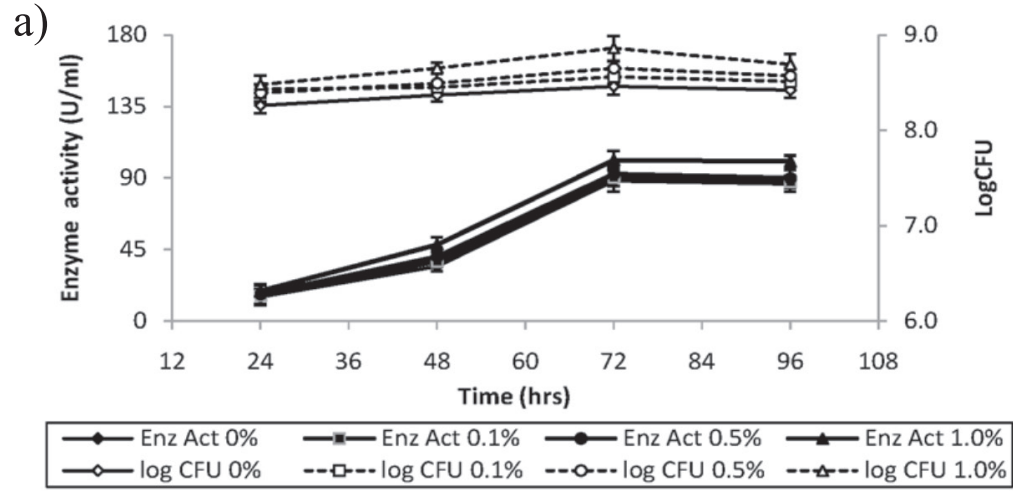

b)

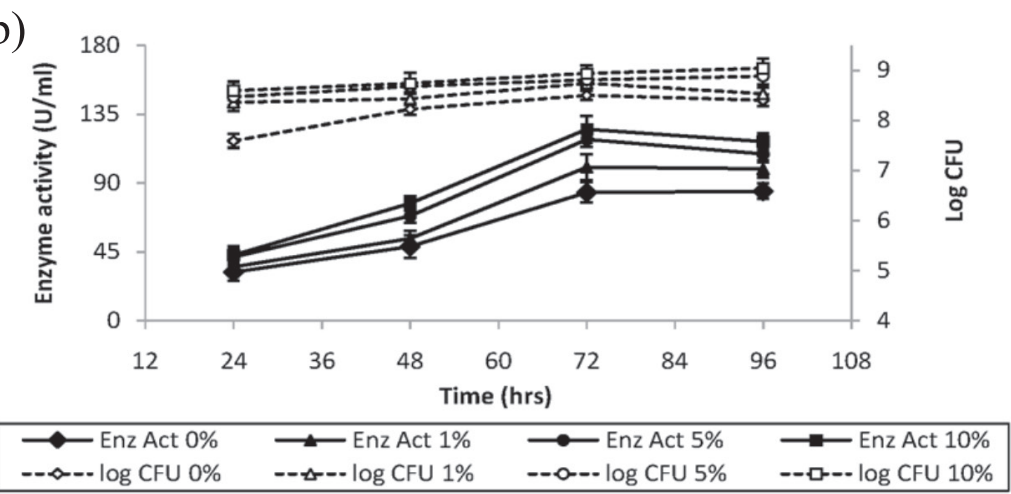

c)

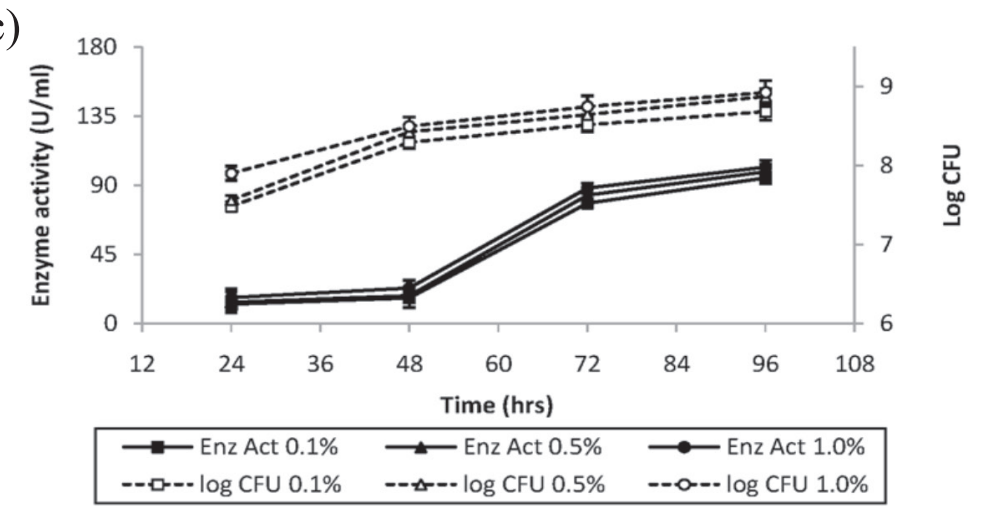

Fig. 3. Optimization of bacterial growth and protease production where a) represents the effect of skim milk concentration, b) represents the effect of $\mathrm{NaCl}$ concentration, and c) represents the effect of $\mathrm{CaCl}_{2}$ concentration; data are the means of three replications \pm standard errors. 
Table 2. Analysis of whey during its fermentation by Bacillus thuringiensis.

\begin{tabular}{|c|c|c|c|c|c|c|c|}
\hline $\begin{array}{c}\text { Time } \\
(\mathrm{hrs})\end{array}$ & $\begin{array}{c}\text { Specific } \\
\text { activity* }\end{array}$ & $\begin{array}{c}\mathrm{pH} \\
\text { value }\end{array}$ & $\begin{array}{c}\text { E.C } \\
\text { value }\end{array}$ & $\begin{array}{c}\text { Glucose } \\
(\mu \mathrm{g} / \mathrm{ml})\end{array}$ & $\begin{array}{c}\text { Carbohydrates } \\
(\%)\end{array}$ & $\begin{array}{c}\text { Total protein } \\
(\mathrm{mg} / \mathrm{ml})\end{array}$ & $\begin{array}{c}\text { Total lipids } \\
(\mathrm{mg} / \mathrm{ml})\end{array}$ \\
\hline 0 & 1.26 & 7.1 & 24.5 & 26 & 1.65 & 1.40 & 0.52 \\
\hline 12 & 3.15 & 5.6 & 23.9 & 30 & 1.20 & 4.10 & 0.79 \\
\hline 24 & 3.72 & 5.5 & 23.7 & 35 & 0.90 & 5.60 & 0.94 \\
\hline 36 & 6.17 & 5.3 & 23.4 & 53 & 0.71 & 5.80 & 1.12 \\
\hline 48 & 8.00 & 5.2 & 23.7 & 60 & 0.53 & 6.60 & 1.29 \\
\hline 60 & 14.10 & 5.2 & 23.4 & 63 & 0.50 & 7.10 & 1.43 \\
\hline 72 & 14.73 & 5.0 & 23.1 & 59 & 0.47 & 8.10 & 1.49 \\
\hline 96 & 12.14 & 4.9 & 23.3 & 72 & 0.41 & 8.70 & 1.61 \\
\hline
\end{tabular}

${ }^{*}$ Specific activity $=$ Enzyme activity $(\mathrm{U} / \mathrm{ml}) / \log \mathrm{CFU} / \mathrm{ml}$

growth and protease production with increasing the concentration of whey up to $50 \%$, while a clear reduction was observed at $100 \%$ whey concentration. The maximum level of protease production $(95.94 \mathrm{U} / \mathrm{ml})$ and bacterial growth $(8.67 \mathrm{log} \mathrm{CFU} / \mathrm{ml})$ was recorded at $50 \%$ whey during the third day. In the case of the impact of skim milk concentrations on the fermentation process, minimal medium containing $10 \%(\mathrm{v} / \mathrm{v})$ whey at $\mathrm{pH} 7$ was supplemented with various concentrations of skim milk and incubated at $37^{\circ} \mathrm{C}$. Results in (Fig. 3a) showed that the maximum level of protease production $(101.22 \mathrm{U} / \mathrm{ml})$ and bacterial growth $(8.86 \mathrm{log} \mathrm{CFU} / \mathrm{ml})$ were recorded at $1 \%(\mathrm{v} / \mathrm{v})$ skim milk during the third day. The increase of whey or skim milk concentrations in the fermentation medium up to certain limits led to a clear increase of protease production. Meanwhile, the higher concentrations of whey or skim milk showed a reduction of bacterial growth and inhibition of protease production that could be attributed to the decline of the dissolved oxygen in the medium [35].

Simultaneously, the influence of $\mathrm{NaCl}$ concentrations on the fermentation process was investigated. Among the salinity supplemented media, the highest bacterial growth (9.04 log $\mathrm{CFU} / \mathrm{ml}$ ) and maximum protease production $(125.03 \mathrm{U} / \mathrm{ml})$ were recorded in the presence of $10 \% \mathrm{NaCl}$ (Fig. 3b). Proteases from halophilic microorganisms possess the advantage of being stable under high salinity levels. To maintain osmolality in saline environments, the microorganisms adopt mainly two strategies: one followed by most moderately halophilic bacteria, accumulating organic compatible solutes in the cytoplasm, and the second followed by the halobacteria, accumulating inorganic salts in the cytoplasm [36]. The effect of metals on the growth and enzyme production was investigated by adding different levels of metallic salts such as $\mathrm{CaCl}_{2}$ to the minimal growth medium. Data in Fig. 3c) showed that there was no significant difference in the bacterial growth under the tested concentrations of calcium, while protease production was affected and maximum protease activity $(101.58 \mathrm{U} / \mathrm{ml})$ was recorded at $1 \%$ of $\mathrm{CaCl}_{2}$. Sivakumar et al. [37] assumed that the proteolytic activity of $B$. thuringiensis is slightly stimulated by $\mathrm{CaCl}_{2}$ and $\mathrm{MgCl}_{2}$. Also, it was found that $\mathrm{Ca}^{2+}$ activated protease activity extracted from Bacillus sp. [38]. It could be suggested that these metal ions such as $\mathrm{Ca}^{2+}$ play a vital role in protecting the enzyme against thermal denaturation in addition to their task for maintaining the active conformation of the enzyme at higher temperatures [39].

\section{Whey Fermentation, Partial Purification of Protease, and Single-Cell Protein Production}

The ability of different microorganisms to produce metabolites commonly used in the food and pharmaceutical industries using whey as a growth substrate has been studied [40]. Whey-based lactic beverages are a perfect way to reuse liquid whey due to its high nutritional value, low cost and sensory value [41]. Likewise, cheese whey was hydrolyzed with a protease from Bacillus sp., where soluble proteins were increased during the hydrolysis process [42]. In the present study, whey was used as a substrate for the production of protease by $B$. thuringiensis under optimum fermentation conditions. Data in Table 2 showed a considerable increase in the specific activity of protease during the fermentation experiment. The biodegradation process started at a low rate and then gradually increased and reached the maximum value after 3 days. The $\mathrm{pH}$ value was decreased through the fermentation process while electrical conductivity was approximately constant. Glucose

Table 3. Determination of BOD and COD of the whey.

\begin{tabular}{|c|c|c|c|}
\hline Analysis & $\begin{array}{c}\mathrm{BOD} \\
(\mathrm{mg} / \mathrm{l})\end{array}$ & $\begin{array}{c}\mathrm{COD} \\
(\mathrm{mg} / \mathrm{l})\end{array}$ & COD/BOD \\
\hline Before fermentation & 2300 & 25800 & 11.2 \\
\hline After fermentation & 1250 & 3780 & 3.024 \\
\hline
\end{tabular}


Table 4. Partial purification of the extracellular protease of Bacillus thuringiensis grown on minimal medium supplemented with $50 \%$ whey, $1 \%$ skim milk, and $10 \% \mathrm{NaCl}$, and $1 \% \mathrm{CaCl}_{2}$ at $37^{\circ} \mathrm{C}$ after $72 \mathrm{hrs}$.

\begin{tabular}{|c|c|c|c|c|c|c|c|}
\hline Purification & $\begin{array}{c}\text { Volume } \\
(\mathrm{ml})\end{array}$ & $\begin{array}{c}\text { Protein conc. } \\
(\mathrm{mg} / \mathrm{l})\end{array}$ & $\begin{array}{c}\text { Enzymeactivity } \\
(\mathrm{U} / \mathrm{ml})^{1}\end{array}$ & $\begin{array}{c}\text { Enzyme } \\
\text { Total U }\end{array}$ & $\begin{array}{c}\text { Specific } \\
\text { activity }^{2}\end{array}$ & $\begin{array}{c}\text { Fold } \\
\text { purification }^{3}\end{array}$ & $\begin{array}{c}\text { Recovery }^{4} \\
(\%)\end{array}$ \\
\hline Before dialysis & 1000 & 15.2 & 120 & 120000 & 7.9 & 1.0 & 100 \\
\hline After dialysis & 50 & 22.2 & 1700 & 85000 & 76.75 & 9.7 & 69.8 \\
\hline
\end{tabular}

(1) One unit of extracellular protease is the amount of enzyme that produces one micromole of tyrosine at $37^{\circ} \mathrm{C}$ per 30 minutes using casein as a substrate.

(2) Specific Activity was derived by dividing Units $/ \mathrm{mg}$ protein $/ \mathrm{ml}$.

(3) Fold purification was derived by dividing specific activity at $2^{\text {nd }}$ by the specific activity at initial step.

(4) Recovery percentage was derived by dividing total Units $/ \mathrm{ml}$ at $2^{\text {nd }}$ step by the total Units $/ \mathrm{ml}$ at initial step.

concentration was markedly increased $(72 \mu \mathrm{g} / \mathrm{ml})$. Similarly, total proteins and total lipids were increased by more than 6- and 3-fold, respectively, while carbohydrate concentrations decreased throughout the fermentation process.

Before the fermentation process, whey demonstrated high BOD, COD, and COD/BOD ratio. Meanwhile, by the end of the fermentation, these values were reduced by $45.65 \%, 85.34 \%$, and $73.01 \%$, respectively (Table 3 ). The elevated BOD and COD values are attributed to the presence of various organic constituents $[4,43]$. The attenuation of BOD and COD of the whey after bacterial fermentation concurs with the results of Kavitha et al. [44], who reported a sharp lessening of COD and BOD of some dairy wastewater due to aerobic and anaerobic microbial treatments.

At the end of the fermentation process, the protease activity of cell-free supernatant was $120 \mathrm{U} / \mathrm{ml}$, which was increased to $1700 \mathrm{U} / \mathrm{ml}$ after precipitation using ammonium sulfate $(65 \%)$, and the fold purification was 9.7 with recovery $70.8 \%$ (Table 4). At the same time, the obtained results showed that the partially purified protease was sterile. These findings comply with Verma et al. [25], who precipitated and purified protease of thermophilic Bacillus licheniformis. The procedure yielded $3.63 \mathrm{mg}$ protein with 29.04-fold purification with a percent yield of $15.48 \%$. In the same way, about 6.6-fold purification of protease from Bacillus aryabhattai using ammonium sulphate precipitation with a recovery of $54.62 \%$ was reported previously [45].

Single-cell protein is one of the value-added products that can be produced during the microbial fermentation of wastes [46]. In the current study, the optimized $B$. thuringiensis fermentation on minimum medium supplemented with whey and skim milk gave $6000 \mathrm{mg} / \mathrm{l}$ dry weight, in which $2600 \mathrm{mg} / \mathrm{l}$ total proteins were recorded within 3 days. Analogous results were recorded by Nayeem et al. [47], who indicated that whey is a suitable substrate for the production of single cell-protein using Kluyveromyces marxianus. Within $24 \mathrm{hrs}$ of the fermentation process, the biomass yield was $36 \mathrm{mg} / \mathrm{ml}$, in which the crude protein content was $83.33 \%$. Also, Ashok et al. [48] revealed similar findings by using Bacillus subtilis for the fermentation of whey in order to produce a single protein.

\section{Conclusions}

In the present study, a potent proteolytic bacterium was isolated from mangrove rhizosphere soil. Whey was found to be an effective production medium for the extracellular protease. The bacterial isolate was identified as B. thuringiensis. This study concluded that biodegradation of dairy effluent is an effective treatment technology using $B$. thuringiensis. There was a remarkable reduction in BOD and COD after the biodegradation process. After optimization for enzymatic production and bacterial growth, several valuable compounds were produced through the fermentation process as partial pure extracellular protease, soluble proteins, glucose, and lipids. These products were the yield in high dry weight with high total protein. The obtained results highlighted the use of whey as a cheap medium not only for the microbial production of protease but also for the generation of single-cell protein.

\section{Acknowledgements}

The authors gratefully acknowledge the dean of scientific research at Jazan University for funding this work through the research group project No. JUP8/000366. The authors extend their appreciation to all the staff of the Biology Department, Faculty of Science, Jazan University.

\section{Conflict of Interest}

The authors declare no conflict of interest.

\section{References}

1. DE JESUS C., RUTH V., DANIEL S., SHARMA A. Biotechnological alternatives for the utilization of dairy industry waste products. Advances in Bioscience and Biotechnology, 6, 223, 2015.

2. AL-WASIFY R.S., ALI M.N., HAMED S.R. Biodegradation of dairy wastewater using bacterial and 
fungal local isolates. Water Science \& Technology, 76 (11), 3094, 2017.

3. MADHU P.C. Utilization of dairy effluent for food grade protease production using Bacillus sp. American Journal of Bioscience and Bioengineering, 4 (6), 90, 2016.

4. VIDRA A., NEMETH A. Whey utilization in a two-stage fermentation process. Liquid Waste Recovery, 2, 17, 2017.

5. SAVITHA G., JOSHI M.M., TEJASHWINI N., SRIDEVI R.R., ROMA D. Isolation, identification and characterization of a feather degrading bacterium. International Journal of Poultry Science, 6 (9), 689, 2007.

6. RODRIGUES M.A.S., AMADO F.D.R., XAVIER J.L.N., STREIT K.F., FERREIRA J.Z. Application of photoelectrochemical electrodialysis treatment for the recovery and reuse of water from tannery effluents. Journal of Cleaner Production, 16 (5), 605, 2008.

7. KAM S.K., KUMAR A. Hydrolytic enzyme protease in sludge: Recovery and its application. Biotechnology and Bioprocess Engineering. 20, 652, 2015

8. EL-GAYAR K.E. Isolation, identification and characterization of Bacillus subtilis from tap water. Asian Journal of Microbiology, Biotechnology and Environmental Sciences, 19 (4), 817, 2017.

9. ZAGHLOUL T.I., HAROUN M.A., EL-GAYAR K., ABDELAL A. Recycling of keratin-containing materials (Chicken Feather) through genetically engineered bacteria. Polymer-Plastics Technology and Engineering, 43 (6), 1589, 2004.

10. BOCHNER B.R. Global phenotypic characterization of bacteria. FEMS Microbiology Reviewer. 33, 191, 2008.

11. ESSA A.M. Effect of continuous mercury stress on mercury reducing community of some characterized bacterial strains. African Journal of Microbiology Research 6 (6), 125, 2012.

12. ESSA A.M., RADWAN T.E., IBRAHIM W.M., REYAD A.M. Biodegradation of the organophosphorus insecticide diazinon by Pseudomonas aeruginosa isolated from agricultural drainage ditches. Egyptian Journal of Botany. 56 (1), 353, 2016

13. LIN X., LEE C.G, CASLE E., SHIH J.C.H. Purification and characterization of a keratinase from a feather degrading Bacillus licheniformis strain. Applied and Environmental Microbiology, 58 (10), 3271, 1992.

14. EL-GAYAR K.E., ZAGHLOUL T.I., HAROUN M. A., SAEED H.M. Purification of alkaline protease from hydrolyzed chicken feather waste using recombinant Bacillus subtilis strain. Scientific journal of king Faisal university, KSA, 13 (1), 1433, 2012.

15. APHA. Standard methods for the examination of water and wastewater. 21 ${ }^{\text {st }}$ Edition. American Public Health Association, Washington D.C. 2005.

16. ABD EL-AZIZ M., AHMED N.S., SAYED A.F., MAHRAN G.A., HAMMAD Y.A. Production of low-fat ice milk using some milk fat replacers. Proceedings the $4^{\text {th }}$ Scientific Conference of Agricultural Sciences, Assiut, December. 290, 2004.

17. ZOLLNER N., KIRSCH K. Colorimetric method for determination of total lipids. Journal of Experimental Medicine, 135, 545, 1962.

18. SMITH PK., KROHN RI., HERMANSON GT., MALLIA A.K. Measurement of protein using bicinchoninic acid. Anal. Biochem. 150, 76, 1985

19. ABADA E.A. Production optimization of extracellular amidase enzyme by newly isolated Pseudomonas putida AP-2 from agricultural soil. Rend. Fis. Acc. Lincei. 2014.

20. ESSA A.M., El-GAYAR K.E. Characterization of bacteria isolated from domestic wastewater in Jazan, Saudi Arabia. Egypt. J. Exp. Biol. (Bot.), 14 (2), 331, 2018.

21. RAJENDRAN S., KAPILAN R., VASANTHARUBA S. Single cell protein production from papaw and banana fruit juices using Baker's yeast. American-Eurasian J. Agric. \& Environ. Sci, 18 (4), 168, 2018.

22. HITHA C.S., HIMA C.S., YOGESH B.J., BHARATHI S., SEKAR K.V. Microbial utilization of dairy waste for lactic acid production by immobilized bacterial isolates on sodium alginate beads. Int. J. Pure App. Biosci, 2 (4), 55-, 2014.

23. BALDASSO C., BARROS T.C., TESSARO I.C. Concentration and purification of whey proteins by ultrafiltration. Desalination, 278, 381, 2011.

24. HABIB S.M.A., FAKHRUDDIN A.N.M., BEGUM S., AHMED M.M. Isolation and screening of thermostable extracellular alkaline protease producing bacteria from tannery effluents. J. Sci. Res, 4, 515, 2012.

25. VERMA A.S., SHIRKOT P. Production, purification and characterization of a thermophilic alkaline protease from Bacillus lichiniformis MS12. J. Env. Bio-Sci., 29 (1), 69, 2015.

26. WEI S., LIU B., CUI H., FAN R., GUO C., SUN M. Diversity of culturable moderately halophilic bacteria producing extracellular hydrolytic enzymes from marine sediments. Biosci. J., Uberlandia, 34 (6), 1724, 2018.

27. NAWAB A., NIMAT U., MUHAMMED Q., HAZIR R., SHAHID K., ABDUL S., MUHAMMAD A. Molecular characterization and growth optimization of halotolerant protease producing Bacillus subtilis strain BLK1.5 isolated from salt mines of Karak, Pakistan. Extremophiles. 20 (4), 395, 2016.

28. EL-GAYAR K., AL ABBOUD M., ESSA A. Characterization of thermophilic bacteria isolated from two hot springs in Saudi Arabia. Journal of Pure and Applied Microbiology, 11 (2), 743, 2017.

29. JAMARATH T., LINDNER C., POPOVI M., BAJPAI R. Production of amylases and proteases by Bacillus caldolyticus from food industry wastes. Food Technol. Biotechnol, 50 (3), 355, 2012.

30. MUKHERJEE AK., ADHIKARI H., RAI SK. Production of alkaline protease by a thermophilic Bacillus subtilis under solid-state fermentation (SSF) condition using Imperata cylindrica grass and potato peel as low-cost medium: characterization and application of enzyme in detergent formulation. Biochem Eng J. 39, 353, 2008.

31. SHARMIN S., TOWHID H.M.D., ANWAT M.N. Isolation and characterization of a protease producing bacteria Bacillus amovivorus and optimization of some factors of culture conditions for protease production. J. Biol Sci. 5 (3), 358, 2005.

32. ABUSHAM R.A., RAHMAN R.N.Z.R., SALLEH A., BASRI M. Optimization of physical factors affecting the production of thermostable organic solvent-tolerant protease from a newly isolated halotolerant Bacillus subtilis strain Rand. Microbial Cell Factories, 8, 20, 2009.

33. MOON SH., PARULEKAR S.J. A parametric study of protease production in batch and fed-batch cultures of Bacillus firmus. Biotechnol Bioeng. 37, 467, 1991.

34. RAHMAN RNZR., GEOK LP., BASRI M., SALLEH AB. Physical factors affecting the production of organic solvent-tolerant protease by Pseudomonas aeruginosa strain K. Bioresource Technol. 96, 429, 2005.

35. CHU W.H. Optimization of extracellular alkaline protease production from species of Bacillus. Journal of Industrial Microbiology \& Biotechnology, 34 (3), 241, 2007. 
36. MELLADO E., SANCHEZ -PORRO C. VENTOSA A. Proteases produced by halophilic bacteria and archaea. Methods in Biotechnology, In: Microbial Enzymes and Biotransformations, 17, 2008.

37. SIVAKUMAR T., SHANKAR T., VIJYABASKER P., RAMASUBRAMANIAN V. Optimization for keratinase enzyme production using Bacillus thuringiensis TS2. Academic Journal of Plant Sciences, 5 (3), 102, 2012.

38. KUMARI P., JANDAIK S., BATTA S. A thermotolerant protease from Bacillus sp. isolation, characterization, optimization and purification. Journal of Pure and Applied Microbiology. 8 (5), 3667, 2014.

39. SHARMA K.M., KUMAR R., PANWAR S., KUMAR A. Microbial alkaline proteases: Optimization of production parameters and their properties. J Genetic Engineering and Biotechnology, 2017.

40. PESCUMA M., DE VALDEZ G.F., MOZZI F. Wheyderived valuable products obtained by microbial fermentation. Applied Microbiology and Biotechnology, 99 (15), 2015.

41. ABDULALIM T.S., ZAYAN A.F., CAMPELO P.H., et al. Development of new functional fermented product: mulberry whey beverage. J Nutr Food Technol, 1 (3), 64, 2018.

42. CORREA A.P.F., DAROIT D.J., FONTOURA R., MEIRA S.M.M., SEGALIN J., BRANDELLI A. Hydrolysates of sheep cheese whey as a source of bioactive peptides with antioxidant and angiotensin-converting enzyme inhibitory activities. Peptides, 61, 48, 2014.
43. RYAN M.P., WALSH G. The biotechnological potential of whey. Article in Reviews in Environmental Science and Bio/Technology, 2016.

44. KAVITHA R.V., KUMAR S., SURESH R., KRISHNAMURTHY V. Performance evaluation and biological treatment of dairy wastewater treatment plant by up flow anaerobic sludge blanket reactor. International Journal of Chemical \& Petrochemical Technology (IJCPT), 3 (1), 9, 2013.

45. SHARMA K.M., KUMAR R., VATS S., GUPTA A. Production, partial purification and characterization of alkaline protease from Bacillus aryabhattai K3.Int. J Adv. Pharm. Biol. Chem., 3, 290, 2014.

46. SPALVINS K., IVANOVS K., BLUMBERGA D. Single cell protein production from waste biomass: review of various agricultural by-products. Agronomy Research, 16 (2), 1493, 2018

47. NAYEEM M., CHAUHAN K., KHAN S., RATTU G., DHAKA R.K., SIDDUQUI H. Optimization of lowcost substrate for the production of single cell protein using Kluyveromyces marxianus. The Pharma Innovation Journal, 6 (8), 22, 2017.

48. ASHOK G.V., MINAKASHI P.A., PRANITA G.A. Liquid Whey: A potential substrate for single cell protein production from Bacillus subtilis NCIM 2010. Int. J. of Life Sciences, 2 (2), 119, 2014. 